\section{JEJAK TATA NIAGA REMPAH-REMPAH DALAM JARINGAN PERDAGANGAN MASA KOLONIAL DI MALUKU}

\author{
Syahruddin Mansyur \\ Balai Arkeologi Ambon \\ J1. Namalatu-Latuhalat, Nusaniwe-Ambon \\ e-mail: hitam_putih07@yahoo.com
}

\section{Abstrak}

Jaringan perdagangan masa lalu telah menempatkan rempah-rempah sebagai komoditi utama. Jaringan perdagangan ini semakin ramai dengan kedatangan bangsa Eropa sekitar abad ke-16. Dalam konteks perdagangan global, terbentuk jaringan perdagangan yang menghubungkan dunia barat sebagai konsumen dan dunia timur sebagai penghasil komoditi. Maluku dikenal sebagai pusat produksi cengkeh dan pala (Kepulauan Rempah-Rempah). Namun, bagaimana jaringan perdagangan global ini dihubungkan dengan tata niaga lokal. Kajian ini bertujuan untuk memperoleh gambaran tentang tata niaga rempah-rempah dalam kaitannya dengan jaringan perdagangan masa kolonial di Maluku. Dengan tujuan tersebut, kajian ini menggunakan studi kepustakaan terkait dengan data arkeologi dan penelusuran sumber sejarah. Hasil dari kajian ini, diperoleh informasi bahwa tata niaga rempah-rempah masa Kolonial memusatkan dua jenis komoditi, yaitu cengkeh di wilayah Pulau Ambon dan Kepulauan Lease (Haruku, Saparua, dan Nusalaut), serta pala di wilayah Kepulauan Banda (Lonthor, Ay, dan Neira). Tata niaga tersebut sekaligus menerapkan sistem yang berbeda yaitu sistem dati untuk cengkeh dan sistem perken untuk pala.

Kata kunci: Tata niaga, rempah-rempah, jaringan lokal, masa kolonial, Maluku

\section{Abstract}

Spices known as a main commodity in the past trading network. These network become busier ever since the European came in the $16^{\text {th }}$ century. In the global trading context, formed the trading network which connect west world as consumer and east world as commodity producer. Moluccas known as the spice islands. However, how these global trading network get connected with the local trading system. This research aim is to get description about the spices trading system in connection with colonial trading network in Moluccas. By that mean, it used literature study, in connection with archaeological evidence and historical sources investigation. The result are informations that the spices trading system in colonial period are centralize on two kind of commodities, which are cloves in Ambon Island and Lease Islands, also nutmegs in Banda Islands. This trading system also apply two different system, which are "dati" system for cloves and "perken" system for nutmegs.

Keyword: trading system, spice, local network, colonial period, Moluccas

\section{Pendahuluan}

Perdagangan adalah proses interaksi antara individu atau kelompok sosial yang satu dengan lainnya untuk memperoleh komoditas. Dalam perdagangan terkait empat komponen pokok, yaitu: orang yang mengadakan interaksi, barang atau komoditas, transportasi atau alat yang digunakan untuk memindahkan barang atau komoditas, dan kedua belah pihak yang terkait dalam perdagangan (Pusat Penelitian Arkeologi Nasional, 2008). Tata niaga dalam konteks jaringan perdagangan dapat diartikan sebagai upaya sistematis untuk mengatur arus barang dan jasa, yaitu; bagaimana memperoleh dan mengumpulkan barang komoditi serta bagaimana mendistribusikan barang dari tempat asal ke tempat tujuan. Jika diposisikan pada konteks hulu dan hilir, maka upaya memperoleh dan mengumpulkan barang komoditi merupakan bagian hulu dalam sistem tata niaga. Dalam konteks lain, komponen utama yang mendukung tata niaga adalah produsen, pedagang, dan konsumen. Ketiga komponen inilah yang saling terkait dalam sistem jaringan perdagangan.

Jaringan perdagangan masa lalu telah menempatkan rempahrempah sebagai komoditi utama sejak awal masehi dengan adanya kontak antara pedagang nusantara dengan pedagang Cina, Arab dan India. Jaringan perdagangan rempah-rempah ini kemudian semakin ramai dengan kedatangan bangsa Eropa sekitar abad ke-16, ditandai dengan penguasaan atas Malaka - salah satu bandar penting dalam jaringan perdagangan Asia Tenggara - pada tahun 1511 oleh bangsa Portugis. Kedatangan bangsa Eropa ke kawasan Asia tidak lepas dari keberhasilan bangsa Portugis menemukan jalur pelayaran yang menghubungkan daratan Eropa dan Asia melalui Afrika (Sutherland, 2004). Jalur pelayaran 
inilah yang kemudian menjadi jalur alternatif jaringan perdagangan dunia yang sebelumnya merupakan jalur darat. Dengan demikian, dalam konteks perdagangan rempah-rempah, khususnya bagi bangsa Eropa telah terbentuk jaringan yang langsung menghubungkan Asia Tenggara khususnya Kepulauan Nusantara sebagai produsen utama rempah-rempah dan Eropa sebagai konsumen.

Sejak kedatangan bangsa Portugis yang kemudian diikuti oleh bangsa Eropa lain pada abad ke-16, Kepulauan Nusantara menjadi salah satu jalur pelayaran dan perdagangan global, karena merupakan pusat perdagangan rempah-rempah dan hasil bumi lainnya. Jaringan ini ditunjang oleh kondisi geografis, sumber alam, jaringan transportasi laut yang memudahkan pendistribusian hasil komoditi unggulannya, sehingga muncul bandar-bandar besar sebagai pelabuhan utama niaga, yang saling terkoneksi satu dengan yang lain (Wibisono, 2004). Sudah tentu dalam hal tata niaga rempah-rempah, antar wilayah tidak dapat dipisahkan dengan wilayah-wilayah lain yang saling terkait, berperan sebagai wilayah penyangga, penghasil, pendistribusi, ataupun pelabuhan singgah (Harkatiningsih, 2009). Dengan demikian, selain terbentuk jaringan global yang menghubungkan Eropa dan Kepulauan Nusantara, juga terbentuk jaringan Nusantara sebagai bandar transit komoditi sebelum dikirim ke Eropa, serta jaringan lokal yang merupakan jalur untuk mengumpulkan komoditi.

Salah satu komoditi penting dalam jaringan perdagangan masa lalu di nusantara adalah rempah-rempah, yang menempatkan Maluku sebagai penghasil utama jenis cengkeh dan pala. Dalam konteks global perdagangan masa lalu, terbentuk jaringan perdagangan nusantara bagian barat sebagai bandar transit utama dan nusantara bagian timur (Kepulauan Maluku) sebagai produsen utama cengkeh dan pala. Sebagai daerah produsen, Maluku yang merupakan wilayah kepulauan terdiri atas beberapa bandar yang merupakan bandar pengumpul untuk komoditi tersebut sehingga terbentuk pola jaringan antar pulau. Kondisi geografis Maluku yang terdiri atas pulau-pulau besar dan kecil, membentuk wilayah ini sebagai jaringan lokal yang terdiri atas pelabuhan-pelabuhan kecil untuk mengumpulkan komoditi cengkeh.

Berdasarkan latar belakang permasalahan di atas, kajian ini mengajukan poin permasalahan seperti terangkum dalam pertanyaan berikut ini: bagaimana tata niaga rempah-rempah dalam kaitannya dengan jaringan perdagangan masa kolonial di Maluku?

Berdasarkan rumusan masalah di atas, kajian ini bertujuan Kapata Arkeologi Vol 7 Nomor 13 / November 2011 untuk memperoleh gambaran tentang tata niaga rempah-rempah dalam kaitannya dengan jaringan perdagangan masa kolonial di Maluku. Oleh karena itu, kajian ini dimaksudkan untuk melengkapi pembahasan tentang tata niaga rempah-rempah dalam konteks perdagangan masa kolonial di nusantara.

\section{Ruang Lingkup dan Metode Penelitian}

Berdasarkan topik yang dipilih, ruang lingkup pembahasan pada kajian ini, terdiri atas beberapa hal yaitu: pertama, tata niaga cengkeh dan pala yang merupakan komoditi utama wilayah penelitian; kedua, kerangka pembahasan dibatasi pada masa kolonial khususnya pemerintahan Belanda (VOC); ketiga, secara geografis, pembahasan ini dibatasi pada wilayah yang saat ini merupakan wilayah administratif provinsi Maluku.

Sementara itu, penelitian ini terdiri atas tiga tahap, yaitu; pengumpulan data, tahap analisis deskriptif, dan penarikan kesimpulan. Pengumpulan data dilakukan dengan melakukan penulusuran pustaka terkait dengan topik pembahasan, yaitu tinggalan arkeologi yang dapat menggambarkan tata niaga rempah-rempah. Data tentang tinggalan arkeologi, terutama diperoleh dari laporan hasil penelitian arkeologi serta sumber-sumber lain yang dianggap dapat menjawab permasalahan penelitian. Khusus untuk data sebaran benteng diperoleh dari hasil inventarisasi benteng di Maluku yang dilakukan pada tahun 2007 oleh Pusat Dokumentasi Arsitektur bekerjasana dengan Direktorat Sejarah dan Purbakala, Passchier Architects And Consultan Netherland, dan Balai Arkeologi Ambon. Selanjutnya, untuk melengkapi deskripsi tinggalan arkeologi dilakukan pendekatan analogi sejarah, hal ini mengingat keterbatasan data artefaktual dalam upaya rekonstruksi masa lalu (Sharer dan Ashmorer, 1980). Tahap akhir, dilakukan penarikan kesimpulan untuk menjawab permasalahan penelitian yaitu memberi gambaran tentang tata niaga rempah-rempah di wilayah penelitian.

\section{Hasil dan Pembahasan}

\section{a. Rempah-Rempah sebagai Komoditi Utama Perdagangan Masa}

Lampau

Maluku adalah salah satu wilayah penting dalam perdagangan internasional sejak jaman lampau, wilayah ini telah disinggahi oleh kapal-kapal dagang dari kerajaan Sriwijaya, kemudian kerajaan 
Majapahit, dan terus berlanjut pada masa Islam dan masa kedatangan bangsa Eropa. Kontak antara wilayah Maluku dengan wilayah barat Nusantara, dapat ditelusuri melalui Kitab Negarakertagama yang menyebut beberapa wilayah yang memiliki hubungan dengan Kerajaan Majapahit. Wilayah-wilayah tersebut, diantaranya; Wanda (Banda Neira), Ambwan (Ambon), Seran (Seram) di Maluku serta Jilolo/Jailolo dan Bacan di Maluku Utara (Suatika, 2005). Sangat dimungkinkan sejak masa kejayaan Kerajaan Majapahit di Pulau Jawa, wilayah Maluku telah berperan sebagai pusat komoditas rempah-rempah yaitu cengkeh dan pala. Bahkan jauh sebelumnya, menurut Selling (1981), sumbersumber Cina menyebutkan bahwa perdagangan rempah-rempah telah melibatkan pedagang-pedagang Nusantara yang berlayar antara Cina dan India sekitar abad ke-5 dan ke-6 (Kustoro dan Rumere, 2004). Demikian halnya dikemukakan oleh Hall (1968), bahwa mulai abad ke-7, secara teratur pedagang Arab yang kebanyakan datang dari India berlayar ke Asia Tenggara. Perdagangan secara meluas tidak saja dilakukan di Nusantara bahkan mencapai belahan selatan Cina (Ibid). Dan pada abadabad selanjutnya pedagang-pedagang Arab kemudian datang dengan membawa dan menyebarkan agama Islam di Nusantara.

Gambaran awal tentang perdagangan rempah-rempah sebelum kedatangan bangsa Eropa, sebagaimana dicatat oleh Tome Pires yang ditulis kembali oleh Armando Cortesao (1944), dalam bukunya The Summa Oriental of Tome Pires, menyebutkan bahwa hingga abad ke-15 perdagangan rempah-rempah didominasi oleh para pedagang muslim. Rute perdagangan yang terbentuk, yaitu pedagang Melayu mengambil rempah-rempah dari Maluku yang kemudian dibawa ke Malaka sebagai salah satu pusat perdagangan terbesar Asia. ${ }^{8}$ Selanjutnya, menurut Muller Kruger (1966), komoditi tersebut dikirim ke Gujarat, Ormus, dan seterusnya ke Istambul melalui Laut Merah, dan dari sinilah kemudian dilanjutkan pedagang Venesia ke Eropa (Sewang, tanpa tahun).

Seperti telah diketahui bahwa kepentingan utama bangsa Kolonial datang ke wilayah ini diawali oleh kepentingan ekonomi. Di dataran Eropa pada saat itu perdagangan rempah-rempah sangat ramai dan banyak diminati oleh orang-orang Eropa yang digunakan sebagai bahan untuk menambah rasa masakan dan sebagai bahan untuk membuat wewangian. Keuntungan yang diperoleh melalui perdagangan rempahrempah sangatlah besar karena setiap berpindah tangan keuntungan yang diperoleh mencapai $100 \%$ sehingga setibanya di Eropa dapat mencapai seribu persen (Hanna, 1983). Demikianlah, maka negara-negara Eropa kemudian berlomba-lomba "menjemput emas" (dengan mendatang sentra produksi rempah-rempah di dunia timur) untuk mendapat keuntungan yang berlipat.

Sejarah kedatangan orang-orang Eropa ke wilayah ini diawal oleh bangsa Portugis. Portugis pada tahun 1511 berhasil menguasai Malaka sebagai salah satu pusat perdagangan rempah-rempah yang kemudian berhasrat untuk mendatangi sentra produksi rempah-rempah di Maluku. Setelah keberhasilan tersebut, Portugis kemudian mencapai keberhasilan berikutnya yaitu menguasai sentra produksi rempahrempah dengan melakukan kerjasama perdagangan dengan Ternate pada tahun 1512. Pada awalnya, daerah pertama yang mereka datangi adalah Kepulauan Banda akan tetapi kemudian ditinggalkan dan menuju ke utara yaitu Ternate karena dianggap sebagai Kerajaan yang berpengaruh dan menguasai wilayah Maluku (Ricklefs, 2008).

\section{b. Data Arkeologi}

Berdasarkan hasil penelitian yang telah dilakukan, data arkeologi yang dapat memberi informasi tentang jejak tata niaga rempah-rempah di Maluku, diantaranya; benteng, loji (gudang), dan perk (kompleks perkebunan pala)

\section{- Benteng}

Secara umum, benteng merupakan bangunan yang berfungsi sebagai simbol pertahanan. Namun, seiring berbagai aktivitas yang dipusatkan dalam benteng termasuk aspek ekonomi dan sosial sehingga mempengaruhi fungsi benteng sebagai pusat administrasi, pemerintahan, dan perdagangan. Pergeseran fungsi terjadi pada benteng-benteng yang dibangun oleh perusahaan dagang bangsa Eropa masa lalu (Marihandono, 2008). Hal ini, karena bentuk benteng berupa tembok (dinding) keliling yang dilengkapi dengan senjata sehingga memberi rasa aman terhadap ancaman yang datang dari luar. Tentu saja, pergeseran fungsi tersebut disertai dengan berbagai fasilitas yang dapat mendukung aktifitas yang dipusatkan dalam benteng. Gill (1995), bahkan menyebut bahwa benteng identik dengan dominasi kekuasaan, eksploitasi ekonomi dan simbol kekuasaan asing di suatu daerah yang dikuasai oleh raja-raja dan penguasa pribumi (Ibid).

Berdasarkan bentuk dan ukurannya, benteng dapat dikelompokkan menjadi empat jenis, yaitu: 
1. Pagger: merupakan bentuk sederhana sebuah benteng yang hanya dilengkapi dengan pagar kayu keliling;

2. Battery/beukery: bangunan pertahanan kecil yang berdiri sendiri untuk menempatkan sejumlah meriam atau senjata, pada umumnya berbentuk setengah lingkaran dan persegi empat dengan ukuran \pm 4 $\mathrm{x} 4$ meter dengan tinggi 4 meter;

3. Redoute: kubu pertahanan yang berukuran lebih besar jika dibandingkan dengan battery, yaitu \pm 8 hingga 10 meter, berbentuk persegi untuk menempatkan meriam. Jenis ini umumnya dapat dikembangkan menjadi benteng yang lengkap.

Blokhuis: bangunan yang pada awalnya lebih difungsikan sebagai gudang komoditi, pada umumnya berbentuk persegi, terbuat dari kayu, dan batu atau beton. Kemudian, dapat dikembangkan sebaga benteng lengkap dengan adanya bastion, yang berfungsi sebagai pos pertahanan;

Klein fort: bangunan pertahanan, umumnya berbentuk persegi, memiliki bastion (sudut yang menjorok keluar, berbentuk segitiga atau melingkar). Jenis ini memiliki ukuran lebih besar dibanding redoute, dan memiliki berbagai bangunan yang difungsikan sebagai kantor, maupun gudang. Namun, jenis ini lebih mengutamakan fungsi pertahanan dengan adanya bastion. Seiring dengan kebutuhan, jenis redoute dan blokhuis dapat ditingkatkan menjadi jenis klein fort dengan menambahkan tembok keliling dengan ukuran yang lebih besar. Hal ini, dapat dilihat pada benteng Amsterdam yang ada di Hila (Pulau Ambon). Pada awalnya hanya berupa blokhuis, kemudian diperkuat dengan tembok keliling dengan tambahan bastion pada tiap sudutnya;

4. Groote forten/Kasteelen: bangunan pertahanan, umumnya berbentuk persegi atau bulat. Jenis ini berukuran lebih besar dibanding klein fort, dengan berbagai fasilitas di dalamnya, seperti kantor, barak militer, gereja, rumah sakit dan tempat tinggal. Jenis ini pada umumnya merupakan embrio sebuah kota, seperti Fort Rotterdam di Makassar dan Nieuw Victoria di Ambon (Pusat Dokumentasi Arsitektur, 2008).

Secara umum, hasil inventarisasi benteng yang dilakukan oleh PDA pada tahun 2007 berhasil mengidentifikasi jumlah benteng yang ada di Maluku sebanyak 69 titik. Selain benteng, baik benteng kolonial maupun tradisional, objek-objek yang didata termasuk perbentengan yang merupakan peninggalan masa Perang Dunia II (Effendy dan Syahruddin, 2007). Namun, tidak semua titik lokasi tersebut akan ditampilkan sebagai data dalam tulisan ini mengingat kajian ini bertujuan untuk member gambaran tentang jejak tata niaga cengkeh. Dengan demikian, jenis benteng yang memiliki fasilitas perdagangan yaitu redout/blockhuis klein fort dan groote foorten/kasteelen adalah pertimbangan utama dalam pemilahan data tersebut.

Sementara itu, sebaran benteng di Maluku dapat dikelompokkan dalam dua periode yaitu periode Portugis dan periode Belanda. Bentengbenteng Portugis sebagian besar dibangun pada awal abad ke-16 hingga awal abad ke-17, dan Belanda dimulai pada awal abad ke-17 hingga abad ke-19. Meski demikian, benteng-benteng yang dibangun pada awal abad ke-16 hingga awal abad ke-17 oleh Portugis, kemudian diambil alih oleh Belanda untuk memperkuat sistem pertahanan mereka di Maluku.

Berdasarkan pengamatan terhadap keletakan benteng yang ada di Maluku yaitu benteng yang ditempatkan di daerah pesisir dan daerah perbukitan memberikan asumsi bahwa benteng yang dibangun di daerah pesisir berkaitan dengan strategi dan taktik perang maritim. Profil wilayah Maluku yang merupakan wilayah Kepulauan sangat tepat dengan strategi ini. Selain itu, berdasarkan pengamatan terhadap sisa struktur yang ada di sekitar benteng menunjukkan bahwa benteng yang ada di daerah pesisir pada umumnya dilengkapi dengan dermaga

Berdasarkan tabel 1, memperlihatkan bahwa jenis-jenis benteng memiliki fungsi pertahanan dan juga fungsi tambahan yaitu perdagangan. Jenis benteng yang hanya memiliki fungsi pertahanan yaitu battery, hal ini jika melihat bentuk dan ukurannya. Sementara itu, jenis redout/ blockhuis/klein fort dan groote foorten/kasteelen, memiliki fungsi tambahan sebagai gudang komoditi. Keseluruhan benteng yang ada berjumlah 36, jenis battery sebanyak 7, jenis redout/blockhuis/klein fort sebanyak 17, groote foorten/kasteelen sebanyak 9, dan 3 benteng tidak dapat diidentifikasi.

Jika memperhatikan tahun pendirian benteng-benteng yang ada di Maluku, sejarah penguasaan VOC maupun pemerintah Belanda atas wilayah ini dapat dibagi dalam tiga fase, yaitu:

1. Pada awal kedatangannya, VOC pada saat itu hanya menempatkan wakil-wakil perdagangannya di Maluku. Hal ini karena pada awalnya mereka datang dengan tujuan perdagangan.

2. Fase selanjutnya dengan tujuan monopoli perdagangan rempah- 
rempah dan berbagai komoditi lainnya. Mereka kemudian membangun benteng-benteng pertahanan untuk meredam perlawanan penguasa-penguasa lokal dan memenangkan persaingan dengan pedagang-pedagang asing lainnya. Pada masa ini, mereka mengatur berbagai urusan perdagangan dan hal-hal lainnya di dalam benteng (kehidupan intra muros). Selain membangun benteng yang merupakan bangunan baru, pada umumnya benteng-benteng tersebut merupakan fasilitas-fasilitas perdagangan yang kemudian diperkuat dengan dinding pertahanan dan persenjataan.

3. Dan fase terakhir berlangsung setelah keadaan mulai kondusif dan perlawanan-perlawanan rakyat Maluku berhasil diredam. Fase ini juga ditandai dengan pembangunan berbagai fasilitas di luar benteng oleh Pemerintah Belanda, dengan adanya berbagai fasilitas ini maka kehidupan kota kolonial telah dimulai. Kota-kota yang ada di Maluku seperti Ambon, Banda, Saparua, bahkan kota-kota kecil memperlihatkan hal ini.

\section{- Perk}

Perk merupakan area perkebunan pala yang dilengkapi dengan kompleks pengolahan pala yang terdiri atas beberapa bangunan, diantaranya rumah pengasapan pala, rumah pengawas, dan rumah pekerja. Pada umumnya, kompleks pengolahan pala memiliki tembok keliling. Kebijakan VOC pada awal penguasaannya atas Kepulauan Banda telah menetapkan wilayah ini sebagai pusat utama produksi pala.

Lahan-lahan produktif pala di kepulauan Banda dibagi atas beberapa persil atau yang disebut "perken"(perkebunan). Perken in berukuran kira-kira 625 roeden persegi atau sekitar 12-13 hektar per perk. Perken-perken tersebut diserahkan kepada pihak swasta yang umumnya adalah para pejabat atau orang-orang Belanda yang memiliki modal. Para pengelola perken disebut perkenier yaitu pengelola pala berlisensi yang dapat mengelola lebih dari satu perk dan disediakan 25 orang budak. Untuk pengelolaan setiap perk dinilai 625 rijskalders. Pehitungannya setiap budak mengerjakan 50 roeden dapat memproduksi pala dan fuli per tahun 25 rijskalders. Dengan demikian setiap perk dapat menghasilkan 625 rijskalders setiap tahun (Tim Penelitian, 2009).

Secara umum, rumah pengasapan pala terdiri dari satu unit bangunan yang berbentuk seperti gudang, luasnya sekitar 10 x 5 meter, atapnya dari seng, temboknya berasal dari batu kali, mempunyai satu buah pintu masuk, tidak mempunyai jendela dan tinggi ruangan sekitar 6 meter. Bangunan ini kalau dilihat dari luar bentuknya sama dengan bangunanbangunan rumah pada umumnya. Perbedaan dari rumah tempat tinggal dengan rumah pengasapan pala terlihat pada bagian dalam bangunan. Pada umumnya bagian dalam dari rumah pengasapan pala terdiri dari dua lantai, bagian bawah merupakan lantai tanah dan bagian atas terbuat dari susunan bambu atau pelepah sagu. Bagian bawah berfungsi sebagai tempat menyalakan bara api, sedang bagian atas berfungsi untuk menebar buah pala yang akan diasapi (Suryanto, 1998).

Berdasarkan peta yang dibuat oleh Van de Wall pada tahun 1928 memberikan informasi bahwa secara keseluruhan terdapat 33 perken di Kepulauan banda, dengan rincian: 3 perken di Pulau Banda, 6 perken di Pulau Ay, dan 24 perken di Pulau Lonthor (Wall, 1928).

\section{- Loji}

Loji atau lodge adalah kantor dagang pada masa VOC yang didalamnya terdapat gudang komoditi, gudang amunisi dan hunian bahkan difungsikan sebagai benteng. Di Maluku, bekas struktur bangunan ini berada di Pulau Lonthor, Kepulauan Banda. Lokasi bangunan saat ini merupakan daerah pemukiman, dan sisa struktur yang dapat diamati berupa bekas dinding dan pintu gerbang. Penempatan loji yang ada di Pulau Lonthor, berfungsi sebagai pusat pengumpul komoditas pala untuk kemudian dikirim ke Ambon atau langsung ke Batavia.

\section{- Kepala tongkat dan Surat Penghargaan}

Sistem pemerintahan yang berlaku sejak kedatangan Belanda (VOC), sekitar abad-ke-17 adalah sistem pemerintahan desa yang dikenal dengan negeri. Dalam sistem pemerintahan tersebut, raja memiliki kedudukan tertinggi. Sistem pemerintahan ini merupakan bagian dari campur tangan Belanda, sehingga kedudukan raja sering kali adalah orang-orang yang berpihak kepada kepentingan Belanda. Hal ini dibuktikan dengan adanya semacam penghargaan berupa Kepala Tongkat berwarna emas yang merupakan simbol kekuasaan dalam sistem pemerintahan negeri. Selain Kepala Tongkat tersebut, bentuk penghargaan lain berupa Surat Penghargaan yang berisi tentang pujian terhadap seorang raja yang memiliki prestasi dalam produksi cengkeh. 


\section{c. Tata Niaga Rempah-Rempah Masa Kolonial di Maluku}

Sebagaimana telah diuraikan, bahwa sebelum kedatangan bangsa Eropa perdagangan rempah-rempah di Maluku didominasi oleh pedagang-pedagang Cina, Arab, dan pedagang pribumi. Namun, sejak kedatangan bangsa Eropa perdagangan rempah-rempah menjadi rebutan diantara para pedagang Eropa. Dimulai dengan kedatangan bangsa Portugis pada tahun 1512, kemudian oleh Belanda pada tahun 1599 Persaingan diantara kedua pedagang Eropa tersebut berakhir dengan kemenangan Belanda yang berhasil mengusir Portugis dari Maluku pada tahun 1605. Belanda melalui perusahaan dagangnya yaitu VOC, kemudian menjadikan Ambon sebagai pusat pemerintahan selama tiga masa jabatan Gubernur Jenderal yaitu sejak tahun 1610 hingga tahun 1619 (Ricklefs, 2008).

Keberhasilan Belanda mengusir Portugis, menyebabkan Belanda semakin leluasa menerapkan sistem monopoli rempah-rempah di Maluku. Untuk memantapkan sistem ini, Belanda berusaha meredam berbagai perlawanan lokal di beberapa daerah diantaranya; Hitu (P. Ambon) pada tahun 1634 (Rijoly, 1989), Iha (P. Saparua) pada tahun 1632 (Hitipieuw, 1984), dan Banda (Kep. Banda) pada tahun 1620-an (Ricklefs, 2008).

Berdasarkan data sebaran benteng yang ada menunjukkan bahwa hingga pertengahan abad ke-17, Belanda telah berhasil membangun benteng di tiap pulau yang ada di Maluku (khususnya Pulau Ambon dan Kepulauan Lease serta Kepulauan Banda). Dukungan sistem pertahanan ini semakin memantapkan pula kebijakan untuk memusatkan komoditi rempah-rempah di kedua wilayah yaitu; Pulau Ambon dan Kepulauan Lease, serta Kepulauan Banda. Hal ini ditandai dengan keberhasilan Gubernur de Vlaming pada Januari 1652, untuk mendesak Sultan Ternate Mandar Syah menandatangani perjanjian tentang pelarangan penanaman pohon cengkeh di wilayah Maluku (dan Maluku Utara) kecuali di Pulau Ambon dan pulau-pulau kecil di sekitarnya. Kebijakan ini diikuti pula dengan pemusatan penanaman pohon pala di Kepulauan Banda (Ibid). Tidak hanya fungsi pertahanan, fasilitas berupa gudang komoditi serta dermaga yang melengkapi fungsi perdagangan, menjadikan benteng sebagai sarana pendukung utama tata niaga rempah-rempah di Maluku.

Selanjutnya, untuk menjamin pelaksanaan perjanjian ini, Belanda menerapkan kebijakan lain yaitu pelayaran hongi atau ekspedisi hongitochten. Pelayaran hongi atau armada hongi adalah pengerahan armada kapal yang dipersenjatai untuk melakukan pengawasan terhadap daerah-daerah penghasil cengkeh. Pelayaran hongi telah berlangsung sejak masa pendudukan Portugis dan sistem ini dilanjutkan oleh Belanda setelah berhasil merebut penguasaan atas wilayah ini. Sejak pemerintahan Portugis, telah berlangsung hubungan antara penduduk Leitimor (bagian timur Pulau Ambon) untuk menyediakan perahu pengangkut yang disebut dengan kora-kora (perahu tradisional Maluku). Armada inilah yang kemudian digunakan untuk melaksanakan pelayaran hongi atau pada masa Belanda disebut ekspedisi hongitochten (Pattykaihatu, 2009).

Dalam upaya menguasai perdagangan cengkeh, bangsa Eropa melakukan pembatasan penanaman pohon agar pasokan cengkeh dapat dijaga dan harga dapat dipertahankan. Tentu saja, apabila pasokan cengkeh berlebih maka harga di pasaran akan turun, tetapi jika pasokan cengkeh dapat dipertahankan maka harga komoditi ini dapat dipertahankan pula. Tidak hanya itu, armada ini sekaligus bertujuan untuk melakukan pengawasan terhadap penduduk pribumi agar tetap menjual hasil panen cengkeh mereka kepada Belanda.

Kebijakan lain yang mendukung sistem tata niaga rempahrempah, khususnya cengkeh adalah keberhasilan Belanda mencampuri struktur sosial penduduk pribumi. Di Maluku khususnya di pulau Ambon dan kepulauan Lease, sistem desa dinamakan Negeri. Struktur masyarakat yang dinamakan negeri tersebut sebetulnya baru timbul pada abad ke- 17 ketika VOC mencampuri kehidupan penduduk dengan maksud mengamankan sistem monopolinya. Dalam struktur sosial tersebut, pengaturan tentang tata niaga cengkeh tampak pada tugas dan kewajiban kepala desa (raja) yang telah ditentukan oleh Gubernur yaitu mengawasi penanaman, pemeliharaan dan panen cengkeh. Selain itu, Raja mendapat jatah "kwarto" atau orang-orang yang dapat dipekerjakan mengolah kebun, mencari ikan, memperbaiki rumah maupun pekerjan lain yang bersifat pribadi (Ibid).

Kebijakan selanjutnya adalah sistem tanah dati, yaitu tanah yang dimiliki oleh keluarga batih atau orang-orang yang memiliki marga yang sama, tanah dati ini kemudian diolah oleh keluarga-keluarga batih. Sistem ini telah dikenal sejak masa VOC, dan mengharuskan pemilik tanah dati untuk menanam sejumlah pohon cengkeh yang telah ditentukan sebelumnya. Hasil dari panen cengkeh tersebut kemudian dijual kepada VOC yang juga telah ditentukan harganya. Sistem inilah yang kemudian disebut dengan sistem dati, sehingga pemerintah Belanda melakukan pencatatan yang seksama atas penduduk suatu negeri (desa) serta tanah 
dati dan pohon cengkeh maupun buahnya (Ibid).

Sementara itu, Belanda menerapkan sistem yang berbeda untuk komoditi pala dengan adanya perken atau perkebunan pala. Sistem ini dilakukan dengan membagi tanah-tanah subur di tiap pulau yang ada di Kepulauan Banda, yaitu Pulau Ay, Pulau Lonthor, dan Pulau Banda. Pembagian ini mulai dilakukan sejak tahun 1616, dan selesai pada tahun 1628. Perkebunan pala ini kemudian diserahkan kepada orangorang Eropa yang memiliki modal dengan sistem sewa. Namun, seiring dengan perjalanannya, perkebunan-perkebunan yang telah dibagi tersebut berubah menjadi hak milik, dan mengalami banyak perubahan, baik perluasan areal dengan cara membeli maupun pengurangan areal dengan adanya pembagian dalam bentuk warisan kepada generasi selanjutnya (Rijoly, 2009). Perkebunan-perkebunan ini kemudian diolah dengan mendatangkan pekerja-pekerja dari Jawa, Buton, dan daerah-daerah lain. Sistem pembagian tanah perkebunan, kemudian dilanjutkan dengan mendatangkan tenaga-tenaga pekerja dari luar dimungkinkan karena keberhasilan Belanda menguasai daerah ini.

\section{Penutup}

\section{a. Kesimpulan}

Berdasarkan hasil dan pembahasan yang telah diuraikan, maka dapat disimpulkan bahwa:

1. Dalam sistem monopoli rempah-rempah, Belanda menerapkan tata niaga untuk memperoleh komoditi cengkeh dan pala dengan memusatkan penanaman kedua komoditi tersebut di dua wilayah yaitu Pulau Ambon dan sekitarnya untuk cengkeh serta Kepulauan Banda untuk pala. Hal ini, dilakukan untuk memudahkan pengawasan kedua komoditi tersebut;

2. Terdapat perbedaan sistem tata niaga untuk kedua jenis komoditi rempah-rempah tersebut, yaitu khusus untuk cengkeh, Belanda menerapkan sistem tanah dati yaitu menyerahkan pengolahan tanaman cengkeh kepada pribumi (keluarga dati) untuk selanjutnya dijual kepada Belanda. Sementara itu, komoditi pala menerapkan sistem perken, yaitu sistem sewa lahan kepada pihak ketiga (swasta) untuk pengolahan perkebunan pala. Setiap perken memiliki perk atau kompleks pengolahan pala, yang dikerjakan oleh tenaga-tenaga kontrak yang didatangkan dari luar Kepulauan Banda.

3. Untuk mengamankan keseluruhan sistem tata niaga tersebut,
Belanda menerapkan sistem pertahanan berupa sebaran benteng yang ditempatkan di tiap pulau di Maluku.

4. Sistem tanah dati untuk komoditi cengkeh didukung oleh fungsi tambahan dari benteng dengan adanya fasilitas gudang komoditi. Sementara itu, untuk komoditi pala di Kepulauan Banda dianggap lebih aman sehingga menerapkan sistem perken.

5. Khusus untuk komoditi cengkeh, sistem tata niaga juga menyentuh aspek sosial-politik dengan adanya kerjasama antara Belanda dengan penguasa pribumi serta memanfaatkan sistem kepemilikan lahan untuk mendukung monopoli cengkeh.

\section{b. Saran}

Hasil penelitian ini telah memberikan gambaran tentang tata niaga rempah-rempah masa Kolonial di Maluku. Terkait dengan hal tersebut, penting dikemukakan bahwa gambaran tata niaga rempah-rempah dalam konteks lokal dapat dijadikan masukan untuk melengkapi pembahasan tentang tata niaga rempah-rempah dalam konteks perdagangan masa Kolonial di nusantara. Hasil pembahasan ini sekaligus dapat dijadikan masukan dalam upaya pendirian museum rempah-rempah di Maluku. Upaya ini dimaksudkan untuk melestarikan memori dunia tentang peran Maluku sebagai pusat produksi cengkeh dan pala di masa lalu. Bahwa signifikansi memori kolektif yang hendak dilestarikan adalah peran Maluku dalam melahirkan hubungan internasional di masa lalu, lebih penting lagi telah melahirkan "ke-Indonesia-an" bangsa ini. 


\section{DAFTAR PUSTAKA}

Effendi, Ivan dan Mansyur, Syahruddin. 2007. Draft Awal Laporan Inventarisasi dan Identifikasi Benteng di Propinsi Maluku. Proyek Kerjasama Dirjen Sejarah dan Purbakala, Pusat Dokumentasi Arsitektur Indonesia, Passchier Architects \& Consultan Netherlands, dan Balai Arkeologi Ambon.

Hanna, W.A. 1983. Kepulauan Banda Kolonialisasi dan Akibatnya di Kepulauan Pala. Jakarta: PT. Gramedia.

Harkantiningsih, Naniek. 2009. Pengaruh Kolonial di Nusantara: Penelitian dan Pengembangan. Makalah dalam Evaluasi Hasil Penelitian Arkeologi (EHPA). Denpasar, 5-8 November 2009 : Pusat Penelitian dan Pengembangan Arkeologi Nasional.

Hitipeuw, Frans. 1984. Kerajaan Iha Berinteraksi dengan Segala Suku Bangsa di Abad XVII dalam Perjuangan Nasional. Jakarta: Departemen Pendidikan dan Kebudayaan, Direktorat Sejarah dan Nilai Tradisional, Proyek Inventarisasi dan Dokumentasi Sejarah Nasional.

Kustoro L.P. dan Rumere Y. 2004. Rempah Timur dalam Kuliner Barat: Upaya Penyediaan dan Penggunaannya. Makalah dalam Berkala Arkeologi Sangkhakala, Medan: Balai Arkeologi Medan.

Loth, C. Vincent. 1995. Pioneers and Perkeniers: The Banda Islands in The 17Th Century. Makalah dalam Cakalele, Vol. 6: 13-35.

Marihandono, Joko. 2008. Perubahan Peran dan Fungsi Benteng dalam Tata Ruang Kota. Makalah dalam Wacana: Jurnal Ilmu Pengetahuan Budaya Vol. 10 No. 1, April 2008. Depok: Fakultas Ilmu Pengetahuan Budaya-Universitas Indonesia.

Patikayhatu, dkk., 2009. Sejarah Negeri dan Desa di Kota Ambon. Ambon: Dinas Pariwisata, Kebudayaan, Pemuda dan Olahraga.

Pusat Dokumentasi Arsitektur. 2008. Field Survey Report Mid Year Evaluation: The Inventory and Identification of Fort in Indonesia. Disampaikan dalam Workshop Hasil Indentifikasi Benteng di Indonesia Timur. Jakarta, 12 Juli 2008

Pusat Penelitian Arkeologi Nasional. 2008. Metode Penelitian Arkeologi. Jakarta: Departemen Kebudayan dan Pariwisata, Pusat Penelitian dan Pengembangan Arkeologi Nasional.

Ricklefs. M.C. 2008. Sejarah Indonesia Modern: 1200-2008. Jakarta: Serambi

Rijoly, Frans. 1989. Guide Book, Indonesia-English Edition. Ambon: Museum Siwalima Ambon, Proyek Pembinaan Permuseuman Maluku.

Sewang, Ahmad, M. ) Islamisasis Kerajaan Gowa: abad XVI sampai abad XVII

Sharer and Ashmore. 1980. Fundamentals of Archaeology. California. The Benyamin Publishing Company. Inc

Suantika, I Wayan. 2005. Peran dan Fungsi Benteng Peninggalan Masa Kolonial bagi Pembangunan Daerah Maluku”, Dalam Evaluasi Hasil Penelitian Arkeologi (EHPA). Yogyakarta 2005, : Pusat Penelitian Arkeologi Nasional

Suryanto, Diman. 1998. Laporan Penelitian Arkeologi Kecamatan Kepulauan Banda Neira. Ambon: Balai Arkeologi Ambon.

Sutherland, H. 2004. Kontinuitas dan Perubahan dalam Sejarah Sulawesi Selatan. Makassar: Hasanuddin University Press.

Tim Penelitian. 2009. Laporan Penelitian Arkeologi Pengaruh Kolonial di Kota Kuna Banda (Tahap I). Jakarta: Pusat Penelitan dan Pengembangan Arkeologi Nasional.

Wall, Victor Ido van de. 1928. de Nederlandsche Oudheden in de Molukken. Gravenhage: Martinus Hijhoff.

Wibisono, Sonny Chr. 2004. A Brief History of Research on Trading Ports/ Harbour Sites. Country Report Indonesia. Makalah dalam Workshop on the Archaeology of Early Harbours and Evidence for Inter-Regional Trade. Singapore: ARI-NUS 
Lampiran 1

Tabel 1: Sebaran benteng kolonial (Eropa) yang ada di Maluku

\begin{tabular}{|c|c|c|c|c|c|c|c|}
\hline \multirow[b]{2}{*}{$\mathrm{Ne}$} & \multirow[b]{2}{*}{ Nama Benteng } & \multicolumn{2}{|c|}{ Lokasi } & \multirow{2}{*}{$\begin{array}{l}\text { Bangsa } \\
\text { pendiri }\end{array}$} & \multirow[t]{2}{*}{ Jenis Benteng } & \multirow{2}{*}{$\begin{array}{l}\begin{array}{l}\text { Kondisi } \\
\text { benteng }\end{array} \\
\end{array}$} & \multirow{2}{*}{\begin{tabular}{|c|} 
Tahun \\
Didirikan \\
\end{tabular}} \\
\hline & & $\begin{array}{l}\text { Pulau } \\
\end{array}$ & KotaDesa & & & & \\
\hline 1 & 2 & 3 & 4 & 5 & 6 & 7 & 8 \\
\hline 1 & Kota Lama & Aru & Wokam & Portugis & \begin{tabular}{|l} 
Fort \\
Groote forten
\end{tabular} & $\begin{array}{l}\text { Hampir } \\
\text { musnah }\end{array}$ & 1500 -an (?) \\
\hline 2 & Nassau & Banda & Banda & \begin{tabular}{|l} 
Portugis \\
(Belanda)
\end{tabular} & \begin{tabular}{|l|} 
Groote forten/ \\
Kasteel
\end{tabular} & $\begin{array}{l}\text { Hampir } \\
\text { musnah } \\
\text { the }\end{array}$ & $\begin{array}{l}1529 \\
(160916177\end{array}$ \\
\hline 3 & Nieuw Victoria & Ambon & Ambon & \begin{tabular}{|l}
$\begin{array}{l}\text { Portugis } \\
\text { (Belanda) }\end{array}$ \\
(a)
\end{tabular} & Kasteel & utuh & $\begin{array}{l}1580 \\
-1689 \\
\end{array}$ \\
\hline 4 & \begin{tabular}{|l|l|} 
Leiden \\
(Enkhuizen)
\end{tabular} & Ambon & Hitulama & Belanda & \begin{tabular}{|l} 
Redout/ \\
Blockhuis
\end{tabular} & $\begin{array}{l}\text { Tingyal puing } \\
\text { (masih dapat } \\
\text { dididentifikasi) }\end{array}$ & \begin{tabular}{|l|l|}
1599 \\
-1656
\end{tabular} \\
\hline 5 & Belgica & Banda & Neira & Belanda & Groote forten & Utuh & 1611 \\
\hline 6 & Revengie & Ai & Ai & \begin{tabular}{|l} 
Inggisis \\
(Belanda)
\end{tabular} & Groote forten & $\begin{array}{l}\text { Hampir } \\
\text { musnah }\end{array}$ & $\begin{array}{l}1610 \\
-1615 \\
\end{array}$ \\
\hline 7 & Hollandia & Lonthor & Lonthor & Belanda & Groote forten & \begin{tabular}{|l} 
Hampir \\
musnah
\end{tabular} & 1624 \\
\hline 8 & Hectoria (Oma) & Haruku & Oma & Belanda & & $\begin{array}{l}\text { Tinggal puing } \\
\text { (masih dapat } \\
\text { dididentifikasi) }\end{array}$ & 1627 \\
\hline 9 & Uring (Stom) & Lonthor & Uring & Belanda & Battery & $\begin{array}{l}\text { Hampir } \\
\text { musnah } \\
\end{array}$ & 1624 \\
\hline 10 & Middelburg & Ambon & Passo & Belanda & \begin{tabular}{|l|} 
Redout/ \\
Blockhuis \\
\end{tabular} & $\begin{array}{l}\text { Hampir } \\
\text { musnah }\end{array}$ & $\begin{array}{l}1625 \\
-1688 \\
\end{array}$ \\
\hline 11 & $\begin{array}{l}\text { Dender (de } \\
\text { morgenster) }\end{array}$ & Lonthor & Dender & Belanda & Battery & $\begin{array}{l}\text { Hampir } \\
\text { musnah } \\
\end{array}$ & 1628 \\
\hline 12 & \begin{tabular}{|} 
Hollandia \\
(Honimua)
\end{tabular} & Sapanua & Siri Sori Islam & Belanda & $\begin{array}{l}\text { Redout' } \\
\text { Blockhuis }\end{array}$ & $\begin{array}{l}\text { Tinggal puing } \\
\text { (masih dapatat } \\
\text { diidentifikasis) }\end{array}$ & 1628 \\
\hline 13 & Hardewijk & Seram & Amahai & Belanda & \begin{tabular}{|l|} 
Redout/ \\
Blockhuis
\end{tabular} & 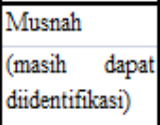 & 1630 \\
\hline
\end{tabular}

\begin{tabular}{|c|c|c|c|c|c|c|c|}
\hline 1 & 2 & 3 & 4 & 5 & 6 & 7 & 8 \\
\hline 14 & Concordia (Orangie) & Lonthor & Wayer & Belanda & $\begin{array}{l}\text { Groote } \\
\text { forten }\end{array}$ & $\begin{array}{l}\text { Hampir } \\
\text { musnah }\end{array}$ & 1630 \\
\hline 15 & Rotterdam & Ambon & Larike & Belanda & \begin{tabular}{|l} 
Redout// \\
Blockhuis
\end{tabular} & $\begin{array}{l}\text { Hampir } \\
\text { musnah }\end{array}$ & 1633 \\
\hline 16 & Amsterdam & Ambon & Hila & Belanda & \begin{tabular}{|l} 
Redout/ \\
Blockhuis// \\
Klein fort
\end{tabular} & utuh & 1637 \\
\hline 17 & Ureng (Vlessingen) & Nusa Telu & Ureng & Belanda & Redout & $\begin{array}{l}\text { Hampir } \\
\text { musnah }\end{array}$ & 1638 \\
\hline 18 & $\begin{array}{l}\text { Seith/Ceith (Sonder } \\
\text { Naam) }\end{array}$ & Ambon & Seith & Belanda & \begin{tabular}{|l} 
Redout// \\
Blockhuis
\end{tabular} & \begin{tabular}{|l|} 
Musnah \\
(tidak dapat \\
diidentifikasi)
\end{tabular} & 1643 \\
\hline 19 & Overburg & Seram & Luhu & Belanda & \begin{tabular}{|l} 
Redout// \\
Klein fort
\end{tabular} & $\begin{array}{l}\text { Hampir } \\
\text { musnah }\end{array}$ & 1647 \\
\hline 20 & Lakui (Halve maan) & Lonthor & Lakui & Belanda & Battery & \begin{tabular}{|l|} 
Tinggal puing \\
(masih dapat \\
diidentifikasi)
\end{tabular} & 1651 \\
\hline 21 & Kuilenberg & Banda & Selamon & Belanda & Battery & Hampir musnah & 1651 \\
\hline 22 & Beverwijk & Nusalaut & Sila & Belanda & \begin{tabular}{|l} 
Redout// \\
Blockhuis
\end{tabular} & $\begin{array}{l}\text { Hampir } \\
\text { musnah }\end{array}$ & 1654 \\
\hline 23 & Haarlem & Ambon & Negeri Lima & Belanda & \begin{tabular}{|l|} 
Redout// \\
Blockhuis
\end{tabular} & $\begin{array}{l}\text { Hampir } \\
\text { musnah }\end{array}$ & 1656 \\
\hline 24 & Hoom & Haruku & Pelau & Belanda & \begin{tabular}{|l} 
Redout/ \\
Klein fort \\
\end{tabular} & $\begin{array}{l}\text { Hampir } \\
\text { musnah }\end{array}$ & 1656 \\
\hline 25 & Delft & Saparua & Porto & Belanda & $\begin{array}{l}\text { Redout/ } \\
\text { Blockhuis }\end{array}$ & \begin{tabular}{|l|} 
Tinggal puing \\
(masih dapat \\
diidentifikasi)
\end{tabular} & 1656 \\
\hline 26 & Wantrouw & Manipa & Tumalehu & Belanda & \begin{tabular}{|l} 
Redout/' \\
Blockhuis
\end{tabular} & $\begin{array}{l}\text { Hampir } \\
\text { musnah }\end{array}$ & 1657 \\
\hline 27 & $\begin{array}{l}\text { Kijk in den pot / } \\
\text { gunung api }\end{array}$ & Gunung Api & Gunung Api & Belanda & battery & $\begin{array}{l}\text { Hampir } \\
\text { musnah }\end{array}$ & 1664 \\
\hline 28 & Vollenhaven & Kisar & Wonreli & Belanda & - & $\begin{array}{l}\text { Hampir } \\
\text { musnah }\end{array}$ & 1665 \\
\hline 29 & Delftshaven & Kisar & Kota Lama & Portugis & \begin{tabular}{|l|} 
Barricade/ \\
Klein fort
\end{tabular} & $\begin{array}{l}\text { Hampir } \\
\text { musnah }\end{array}$ & 1667 \\
\hline
\end{tabular}

Kapata Arkeologi Vol 7 Nomor 13/ November 2011 37 


\begin{tabular}{|c|c|c|c|c|c|c|c|}
\hline \begin{tabular}{|ll}
1 \\
1
\end{tabular} & 2 & 3 & 4 & 5 & 6 & 7 & 8 \\
\hline & Duurstede & Saparua & Saparua & Portugis & Groote forten & Utuh & 1676 \\
\hline & & & & (Belanda) & & & -1691 \\
\hline 31 & $\begin{array}{l}\text { Pin/Kaibobo } \\
\text { (Wambais) }\end{array}$ & Seram & Kaibobo & Belanda & Battery & $\begin{array}{l}\text { Hampir } \\
\text { musnah }\end{array}$ & \\
\hline & & & & & & & -1695 \\
\hline 32 & Defensie & Buru & Kayeli & Belanda & $\begin{array}{l}\text { Groote } \\
\text { Forten }\end{array}$ & $\begin{array}{l}\text { Hampir } \\
\text { musnah }\end{array}$ & 1785 \\
\hline 33 & Sawai & Seram & Sawai & Belanda & & $\begin{array}{l}\text { Tinggal puing } \\
\text { (masih dapatt } \\
\text { dididentifikasi) }\end{array}$ & 1823 \\
\hline 34 & Ouw & Saparua & Ouw & Belanda & & $\begin{array}{l}\text { Tinggal puing } \\
\text { (masih dapat } \\
\text { dididentifikasi) }\end{array}$ & \\
\hline 35 & Rohomoni & Harulku & Rohomoni & & Battery & $\begin{array}{l}\text { Hampir } \\
\text { musnah }\end{array}$ & \\
\hline \multirow[t]{2}{*}{36} & \multirow[t]{2}{*}{ Wahai } & \multirow[t]{2}{*}{ Seram } & \multirow[t]{2}{*}{ Wahai } & \multirow[t]{2}{*}{ Belanda } & Redout & Musnah & \\
\hline & & & & & & $\left(\begin{array}{l}\text { (masih dapat } \\
\text { dididentifiliasii) }\end{array}\right.$ & \\
\hline
\end{tabular}

Diolah dari berbagai sumber.
Lampiran 2

Tabel 2: Sebaran Perk di Kepulauan Banda

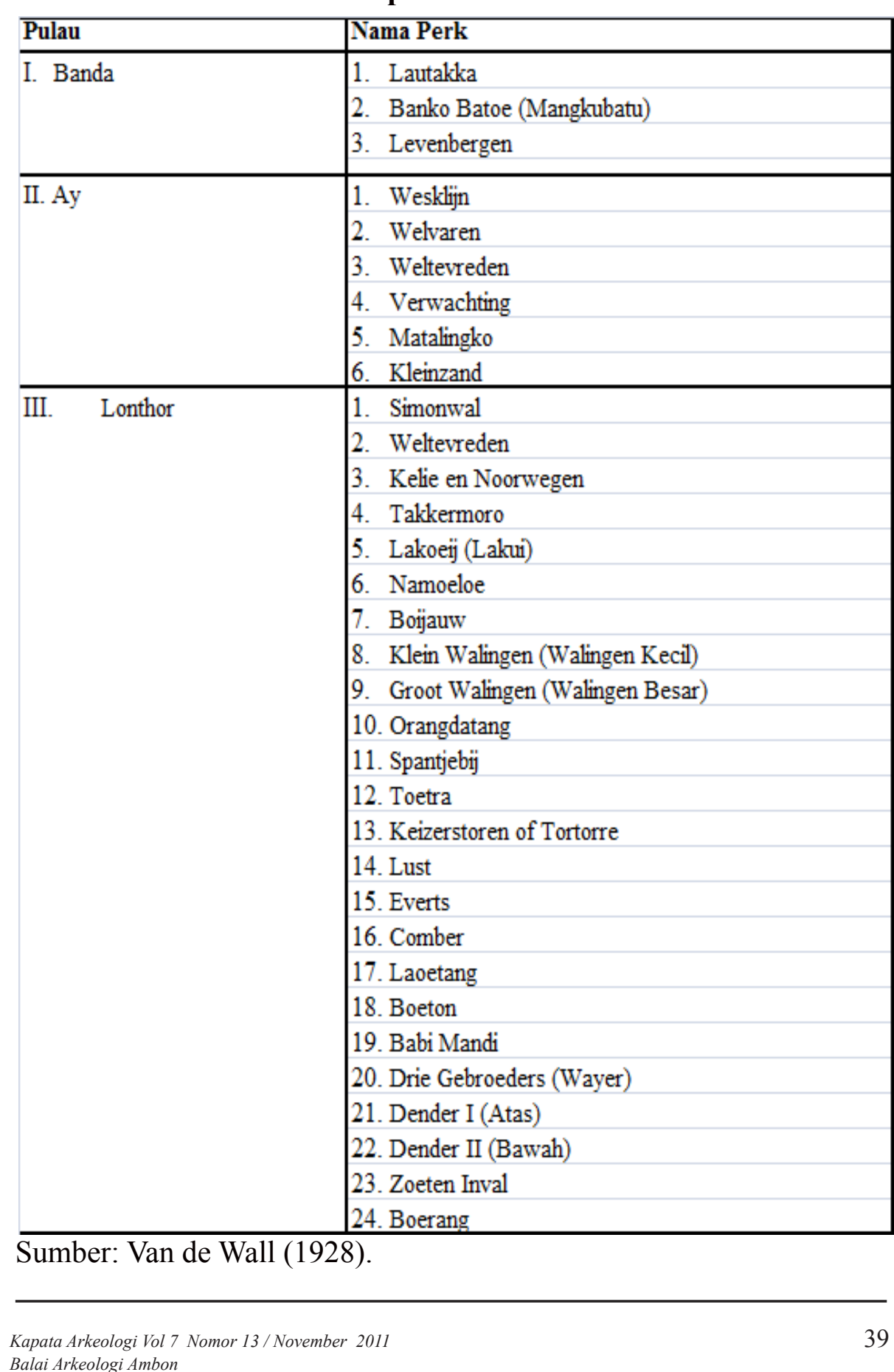

